\section{Ichthyosis: Early Manifestation of Intestinal Leiomyosarcoma}

\section{$\begin{array}{ll}\text { A. E. MAJEKODUNMI, D. FEMI-PEARSE } & \text { D. }\end{array}$}

British Medical fournal, 1974, 3, 724

Acquired ichthyosis has been shown to be associated with the lymphomas, especially Hodgkin's disease (Welch and Epstein, 1952; Sneddon, 1955; Stevanovic, 1960). To our knowledge there have been no reports of this skin lesion in association with leiomyosarcoma. We report the case of a Nigerian man whose ichthyosis was an early feature of leiomyosarcoma of the small intestine. It disappeared after resection and reappeared with recurrence of the tumour.

\section{Case Report}

The patient, a 49-year-old man, was admitted to the Lagos University Teaching Hospital on 15 November 1971 for investigation of a scaly rash on both legs and increasing tiredness of two months' duration. He had also lost some weight.

On examination he appeared well with normal cardiovascular and respiratory systems. There was slight hepatomegaly, $2 \mathrm{~cm}$ below the costal margin, but no lymphadenopathy. Rectal examination showed nothing abnormal. There was an extensive dry scaly eruption on the legs, most pronounced on the extensor aspects, and hyperkeratosis of the soles of the feet. Haemoglobin was $7.9 \mathrm{~g} / 100 \mathrm{ml}$ and P.C.V. $27 \%$. Total serum proteins were 6.9 $\mathrm{g} / 100 \mathrm{ml}$, with a normal electrophoretic strip. There was no biochemical evidenœ of intestinal malabsorption. A few hookworm ova were found in the stools, which on three occasions were positive for occult blood. Sigmoidoscopy and barium swallow and meal showed no abnormality. After two weeks in hospital the haemoglobin had dropped to $5.7 \mathrm{~g} / 100 \mathrm{ml}$ and he was given two pints $(1,136 \mathrm{ml})$ of blood. In view of poor filling of the terminal ileum after barium enema laparatomy was undertaken and a huge tumour resected from the ileum. The surface of the liver was smooth. Histologically the tumour was a leiomyosarcoma.

Two weeks later the ichthyosis had begun to improve. Four months after the operation he was asymptomatic. He failed to keep his subsequent appointments but reappeared in September 1973 with gross abdominal distension due to ascites. The ichthyosis was again apparent on bath legs and had spread to the lower abdomen (see fig.). There was no clear indication of when the ichthyosis had reappeared. His general condition was poor and he died six weeks later. At necropsy there was recurrence of the leiomyosarcoma with extensive spread into the peritoneum.

\section{Comment}

The occurrence of ichthyosis after early childhood warrants detailed investigation. Dijk (1963) reviewed cases of acquired ichthyosis and found that the vast majority of patients had

\footnotetext{
Department of Medicine, Lagos University Teaching Hospital, Nigeria

A. E. MAJEKODUNMI, M.B., M.R.C.P., Senior Registrar

College of Medicine, University of Lagos, Nigeria

D. FEMI-PEARSE, M.D., F.R.C.P., Professor of Medicine
}

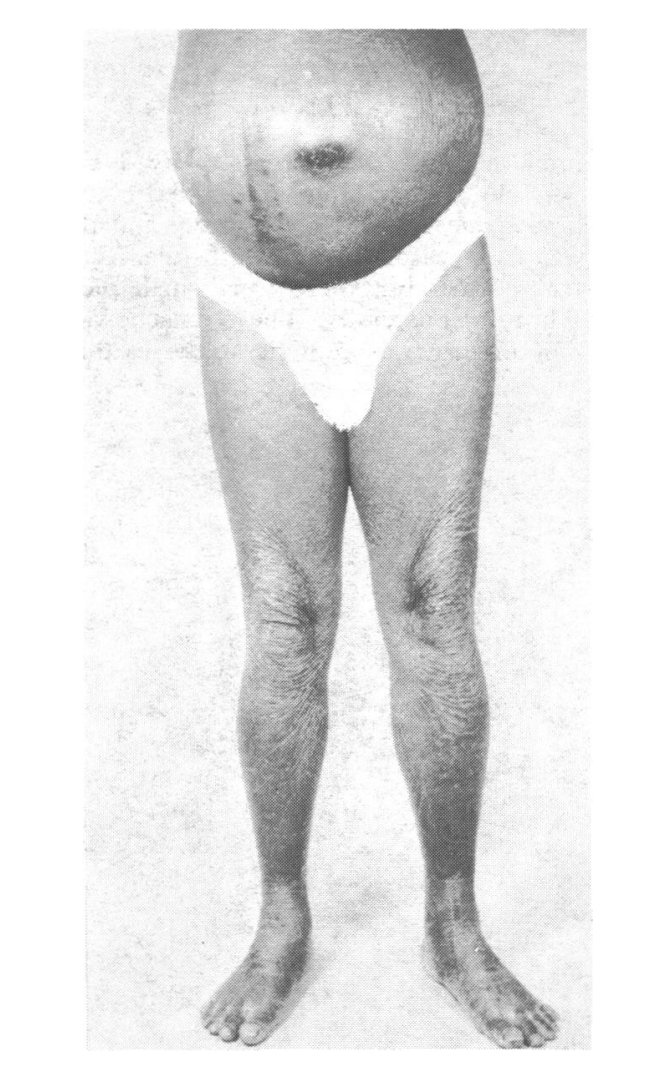

Distribution of ichthyosis at time of second admission.

reticuloses, mostly Hodgkin's disease. It has also been described in carcinoma of the breast (Sneddon, 1970). Acquired ichthyosis usually appears after the first clinical signs of malignancy but it may coincide with or even precede them for as long as seven years (Stevanovic, 1960).

The pathogenesis of acquired ichthyosis is not known. It has been postulated that it is due to hypovitaminosis $\mathrm{A}$. This may result from gross malnutrition or intestinal malabsorption. Though in only a few patients with ichthyosis have the serum vitamin A levels been measured, low values were reported in cases associated with Hodgkin's disease (Degos et al., 1961; Duperrat, et al., 1961). These were isolated cases and the significance of the low serum values is yet to be defined.

Though malnutrition and leprosy are common in the tropics we rarely see cases of frank acquired ichthyosis. Physicians practising in the tropics should be aware of the association of acquired ichthyosis with internal malignancy, and such cases call for detailed investigations.

\section{References}

Degos, R., Lortat-Jacob, E., and Veron, P., (1961). Bulletin do la Societé Franfaise de dermatologie et de Syphilographie, 68, 12

Dijk, E. Van (1963). Dermatologica, 127, 413.

Duperrat, B., Descrez, Pringuet, R., and Puissant, A. (1961). Bulletin de la Societe Franfaise de dermatologie et de Syphilographie, 68, 179.

Sneddon, I. B. (1955). British Medical fournal, 1, 763 .

Sneddon, I. B. (1970). Postgraduate Medical fournal, 46, 678.

Stevanovic, D. V. (1960). Archives of Dermatology, 80, 150.

Welch, J. L., and Epstein, E. (1952). Fournal of the American Medical Association, 148, 1221. 